\title{
Pollution discharge Scenario of Oil and Surfactants Manufacturing Industries along Dombivali Industrial Belt of Mumbai, India
}

\author{
P. U. Singare ${ }^{1, *}$, S. S. Dhabarde ${ }^{2,3}$ \\ ${ }^{1}$ Department of Chemistry, Bhavan's College, Munshi Nagar, Andheri (West), Mumbai, \\ Maharashtra 400058, India \\ ${ }^{2}$ Department of Chemistry, K.V. Pendharkar College, Dombivali (East), Dist. Thane, \\ Maharashtra 421201, India \\ ${ }^{3}$ Department of Chemistry, Pacific University of Higher Education \& Research University, \\ Udaipur, Rajasthan, India \\ *E-mail address: pravinsingare@gmail.com
}

\begin{abstract}
The paper deals with monitoring of pollution arising due to oil and surfactants manufacturing industries located along the Dombivali industrial belt of Mumbai, India. The study was carried for the period of one year from June, 2012 to May, 2013 to study the level of toxic heavy metals and the physico-chemical properties of waste water effluents discharged from the above industries. The maximum concentration of majority of heavy metals like $\mathrm{Cu}, \mathrm{Ni}, \mathrm{Cr}, \mathrm{Pb}$ and $\mathrm{Fe}$ were recorded as $13.48,3.90,13.30,1.75$ and $15.89 \mathrm{ppm}$ respectively, which were above the tolerable limit set for inland surface water. The maximum $\mathrm{pH}$ and conductivity values of the industrial waste water effluent were recorded as 10.05 and $27800 \mu \mathrm{mhos} / \mathrm{cm}$ respectively. The majority of physico-chemical parameters like chloride, cyanide, phosphate and total solid content were found to be maximum in the month of March having the respective values of 2340, 0.09, 35.2 and $8755 \mathrm{ppm}$. The effluent samples collected in the month of May was found to have low DO content of $3.33 \mathrm{ppm}$ and high BOD content of $643 \mathrm{ppm}$. The alkalinity and COD values were reported to be maximum of 1988 and $4410 \mathrm{ppm}$ respectively in the month of February. The hardness and salinity content was reported maximum of 131 and $5.76 \mathrm{ppm}$ during the month of December and June respectively. The results of present research work indicates that time has come to move towards ecosystem specific discharge standards to maintain the health and productivity of natural resources on which the majority of Indians are dependent.
\end{abstract}

Keywords: effluents; physico-chemical analysis; heavy metals; oil and surfactant industries; Dombivali industrial belt; Mumbai

\section{INTRODUCTION}

Synthetic surfactants are economically important chemicals. Surfactants are a diverse group of chemicals that are designed to have cleaning or solubilisation properties. They are widely used in household cleaning detergents, personal care products, textiles, paints, 
polymers, pesticide formulations, pharmaceuticals, mining, oil recovery and pulp and paper industries.

The world production of synthetic surfactants amounts to 7.2 million tons annually [1]. Surfactants consisted mainly of three types: anionic, nonionic and cationic. Linear alkylbenzene sulphonates $(L A S)$ are the most popularly used synthetic anionic surfactants. It has been extensively used for over 30 years with an estimated global consumption of 2.8 million tons in 1998 [2]. Alkylphenol ethoxylates $(A P E)$ constitute a large portion of the nonionic surfactant market.

The worldwide production of APEs was estimated at 500,000 tons in 1997 with $80 \%$ of nonylphenol ethoxylates (NPE) and $20 \%$ of octylphenol ethoxyalyes (OPE) [3]. APEs are discharged to wastewater treatment facilities or directly released into the environment. Concern has increased recently about the wide usage of $A P E$ because of their relatively stable biodegradation products [4].

Many studies have reported on the wide occurrence of $A P E$ metabolites in the environment [5-10]. These metabolites have been demonstrated to be toxic to both marine and freshwater species [11,12], and to induce estrogenic responses in fish [13,14]. Studies have found that $A P E$ metabolites are more toxic than the parent substances and possess the ability to mimic natural hormones by interacting with the estrogen receptor $[3,13,15,16]$.

The levels of these $A P E$ metabolites present in the environment may be well above the threshold necessary to induce endocrine disruption in wildlife. These findings have raised public concern over their environmental and human health effects.

Considering the environmental impact of pollution arising from oil and surfactants manufacturing industries at global level, in the present investigation attempts was made to carry out the comprehensive survey of pollution arising due to such industries located in Dombivali MIDC industrial belt which is considered to be one of the most polluted industrial belts of Mumbai.

\section{EXPERIMENTAL}

\section{1. Study area}

The Dombivali industrial area was established by Maharashtra Industrial Development Corporation (M.I.D.C) in 1964. The industrial belt occupies an area of about 347.88 hector, is located in south of Ulhas River and about $45.00 \mathrm{~km}$ from Mumbai international airport. There are about 30 highly polluting small /medium/ large scale chemical industries located in this industrial belt.

Quantity of industrial effluent generated in the industrial area is about 14 MLD, which is finally discharged into the creek through open drainages which was passing through residential area [17].

\section{2. Climatic condition}

Dombivali enjoys a tropical climate with mean annual temperature of $24.3{ }^{\circ} \mathrm{C}(\mathrm{min})$ to $32.9^{\circ} \mathrm{C}(\max )$. The hottest and driest part of the year is April-May, when temperature rises to $38.0{ }^{\circ} \mathrm{C}$. The humidity is usually in the range of 58 to $84 \%$ and sea breeze in the evening hours is a blessing to combat the high temperature and humidity during summer months.

The average southwest monsoon rainfall is in the range of $1850 \mathrm{~mm}$ to $2000 \mathrm{~mm}$. The average annual rainfall in the region is the range from 1286 to $1233 \mathrm{~mm}$ [17]. 


\section{3. Requirements}

All the chemicals and reagent used for analysis were of analytical reagent grade. The glasswares used in the analysis were washed with distilled de-ionized water; the pipettes and burette were rinsed with the experimental solution before final use.

\section{4. Industrial Effluent Sampling and Preservation}

The industrial waste water effluent samples were collected randomly twice in a month in morning, afternoon and evening session from three representative oil and surfactant manufacturing units of Dombivali industrial belt of Mumbai. The samples were collected every month from June, 2012 to May, 2013.

Polythene bottles of $2.5 \mathrm{~L}$ and $2.0 \mathrm{~L}$ were used to collect the grab water samples (number of samples collected, $n=20$ ). The bottles were thoroughly cleaned with hydrochloric acid, washed with tape water to render free of acid, washed with distilled water twice, again rinsed with the water sample to be collected and then filled up the bottle with the sample leaving only a small air gap at the top. The sample bottles were stoppard and sealed with paraffin wax.

\section{5. Physico-chemical Study}

The samples were collected were analyzed for $\mathrm{pH}$, conductivity, alkalinity, hardness, salinity, chloride, cyanide, phosphate content, Total Dissolved Solids (T.D.S), Total Suspended Solids (T.S.S), Total Solids (T.S), Dissolved Oxygen (D.O), Bio-chemical Oxygen Demand (B.O.D) and Chemical Oxygen Demand (C.O.D) values.

The techniques and methods followed for collection, preservation, analysis and interpretation are those given by Rainwater and Thatcher [18], Brown et al. [19], I.C.M.R [20], Hem [21] and A.P.H.A [22].

\section{6. Heavy Metal Analysis by AAS Technique}

Water samples $(500 \mathrm{~mL})$ were filtered using Whatman No. $41(0.45 \mu \mathrm{m}$ pore size $)$ filter paper for estimation of dissolved metal content. Filtrate $(500 \mathrm{~mL})$ was preserved with $2 \mathrm{~mL}$ nitric acid to prevent the precipitation of metals. The samples were concentrated on a water bath depending on the suspected level of the metals [23].

The analysis for the majority of the trace metals like copper $(\mathrm{Cu})$, nickel $(\mathrm{Ni})$, chromium $(\mathrm{Cr})$, lead $(\mathrm{Pb})$, iron $(\mathrm{Fe})$ and zinc $(\mathrm{Zn})$ was done by Perkin Elmer ASS-280 Flame Atomic Absorption Spectrophotometer. The calibration curves were prepared separately for all the metals by running different concentrations of standard solutions.

A reagent blank sample was run throughout the method, and the blank readings were subtracted from the samples to correct for reagent impurities and other sources of errors from the environment. Average values of three replicates were taken for each determination.

\section{RESULTS AND DISCUSSION}

The experimentally measured pollution data on heavy metal content and physicochemical properties of industrial waste water effluents released from oil and surfactants industries located along Dombivali industrial belt of Mumbai is presented in Tables 1 and 2 . 
Table 1. Physico-chemical properties of the effluents released from Oil and Surfactants Manufacturing industries located along Dombivali Industrial Belt of Mumbai, India.

\begin{tabular}{|c|c|c|c|c|c|c|c|c|c|c|c|c|}
\hline 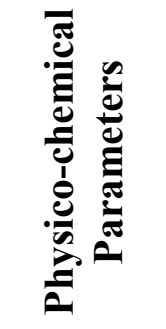 & 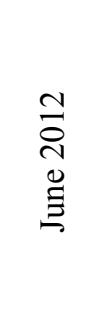 & $\begin{array}{l}\underset{N}{D} \\
\stackrel{N}{2} \\
\stackrel{\lambda}{\Xi}\end{array}$ & 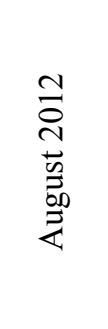 & $\begin{array}{l}\text { N } \\
\overline{0} \\
\dot{0} \\
\overline{0} \\
\overline{0} \\
\stackrel{0}{0} \\
\tilde{D}\end{array}$ & $\begin{array}{l}\stackrel{N}{0} \\
\stackrel{2}{0} \\
\dot{0} \\
0 \\
0 \\
0 \\
0\end{array}$ & 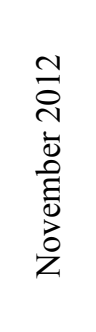 & 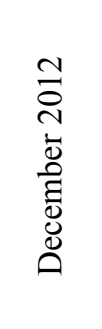 & 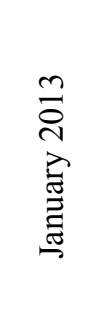 & 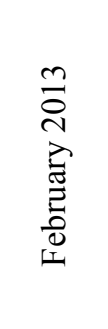 & 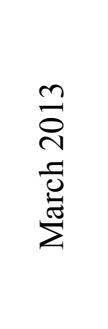 & 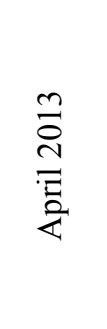 & 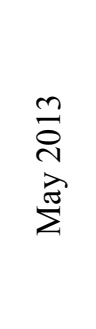 \\
\hline $\mathrm{pH}$ & 8.33 & 10.00 & 8.46 & 8.48 & 9.85 & 9.86 & 9.35 & 10.05 & 9.40 & 8.90 & 9.67 & 9.45 \\
\hline $\begin{array}{l}\text { Conductivity } \\
(\mu \mathrm{mhos} / \mathrm{cm})\end{array}$ & 27800 & 24976 & 16740 & 11540 & 5298 & 7565 & 9865 & 6550 & 10000 & 12500 & 10328 & 11395 \\
\hline $\begin{array}{l}\text { Alkalinity } \\
\text { (ppm) }\end{array}$ & 431 & 565 & 357 & 454 & 790 & 941 & 1684 & 1780 & 1988 & 188 & 1951 & 1935 \\
\hline $\begin{array}{l}\text { Hardness } \\
(\mathrm{ppm})\end{array}$ & 99 & 102 & 110 & 116 & 118 & 99 & 131 & 96 & 99 & 100 & 97 & 113 \\
\hline $\begin{array}{l}\text { Salinity } \\
\text { (ppm) }\end{array}$ & 5.76 & 4.39 & 5.00 & 4.75 & 4.40 & 4.49 & 4.50 & 4.99 & 4.54 & 5.00 & 4.35 & 4.44 \\
\hline $\mathrm{Cl}^{-}(\mathrm{ppm})$ & 301 & 457 & 601 & 750 & 1109 & 1660 & 2021 & 2090 & 2127 & 2340 & 2276 & 2110 \\
\hline $\mathrm{CN}^{-}(\mathrm{ppm})$ & 0.04 & 0.05 & 0.05 & 0.06 & 0.05 & 0.06 & 0.07 & 0.06 & 0.07 & 0.09 & 0.08 & 0.07 \\
\hline $\begin{array}{l}\text { Phosphates } \\
\text { (ppm) }\end{array}$ & 7.6 & 8.8 & 9.5 & 10.2 & 10.4 & 18.2 & 14.6 & 23.2 & 33.5 & 35.2 & 34.8 & 32.3 \\
\hline TDS (ppm) & 2510 & 2745 & 3056 & 3275 & 3600 & 4370 & 3975 & 3203 & 6600 & 6780 & 6580 & 6054 \\
\hline TSS (ppm) & 39.0 & 75.4 & 290.4 & 453.8 & 1120.0 & 1347.9 & 1590.3 & 1780.4 & 1810.0 & 1975.0 & 1659.5 & 1680.5 \\
\hline TS (ppm) & 2549.0 & 2820.4 & 3346.4 & 3728.8 & 4720.0 & 5717.9 & 5565.3 & 4983.4 & 8410.0 & 8755.0 & 8239.5 & 7734.5 \\
\hline D.O (ppm) & 4.26 & 3.35 & 4.00 & 3.99 & 3.75 & 4.05 & 4.40 & 4.80 & 3.37 & 3.90 & 3.65 & 3.33 \\
\hline $\begin{array}{l}\text { B.O.D } \\
\text { (ppm) }\end{array}$ & 356 & 490 & 540 & 524 & 511 & 525 & 605 & 595 & 610 & 501 & 551 & 643 \\
\hline $\begin{array}{l}\text { C.O.D } \\
\text { (ppm) }\end{array}$ & 251 & 270 & 438 & 954 & 2393 & 3548 & 2369 & 3958 & 4410 & 4205 & 3861 & 4001 \\
\hline
\end{tabular}


Table 2. Heavy Metal content in the effluents released from Oil and Surfactants Manufacturing industries located along Dombivali Industrial Belt of Mumbai, India.

\begin{tabular}{|c|c|c|c|c|c|c|c|c|c|c|c|c|}
\hline 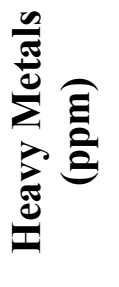 & 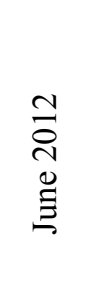 & $\begin{array}{l}\stackrel{ }{\partial} \\
\stackrel{N}{N} \\
\stackrel{\lambda}{\Xi}\end{array}$ & 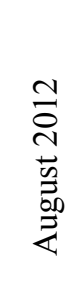 & 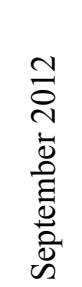 & 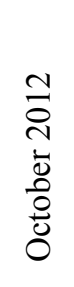 & 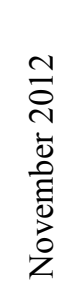 & 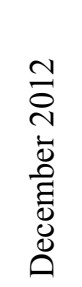 & 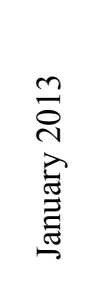 & 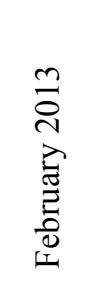 & 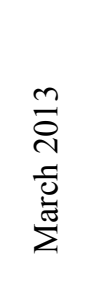 & $\begin{array}{l}\frac{m}{\sigma} \\
\frac{i}{\vec{z}} \\
\frac{\bar{z}}{2}\end{array}$ & 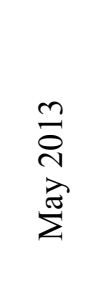 \\
\hline $\mathrm{Cu}$ & 0.54 & 0.48 & 1.56 & 1.98 & 2.34 & 3.75 & 6.98 & 9.49 & 13.48 & 12.98 & 10.50 & 13.35 \\
\hline $\mathrm{Ni}$ & 0.45 & 0.32 & 0.66 & 0.52 & 0.65 & 0.59 & 0.80 & 0.62 & 0.67 & 1.09 & 3.90 & 0.57 \\
\hline $\mathrm{Cr}$ & 0.55 & 0.49 & 0.68 & 1.54 & 0.55 & 1.50 & 0.65 & 4.59 & 11.10 & 13.30 & 12.75 & 10.20 \\
\hline $\mathrm{Pb}$ & 1.24 & 1.70 & 1.60 & 1.30 & 1.75 & 1.00 & 0.98 & 1.39 & 0.76 & 0.97 & 1.25 & 1.20 \\
\hline $\mathrm{Fe}$ & 1.24 & 2.65 & 4.45 & 4.90 & 5.42 & 8.68 & 9.98 & 10.10 & 15.89 & 14.50 & 15.60 & 15.79 \\
\hline $\mathrm{Zn}$ & 0.72 & 0.86 & 0.98 & 1.00 & 1.03 & 1.57 & 1.95 & 2.43 & 2.73 & 2.56 & 2.87 & 2.75 \\
\hline
\end{tabular}

Trace elements are those elements which are present in relatively low concentration of less than few ppm. Among the special group of trace elements are the heavy metals which are having the potential to create health hazards among humans, plants and other aquatic biological life. Under the group of heavy metals are $\mathrm{Cr}, \mathrm{Ni}, \mathrm{Zn}, \mathrm{Cu}, \mathrm{Pb}$ and $\mathrm{Fe}$. They are classified under the group of heavy metals because in metallic form they have the densities higher than $4 \mathrm{~g} / \mathrm{cm}^{3}$.

The $\mathrm{Cu}$ content in the effluent samples collected was found to be vary in the range of $0.48 \mathrm{ppm}$ in the month of July to maximum of $13.48 \mathrm{ppm}$ in the month of February. The values reported were above the permissible limit of $0.05 \mathrm{ppm}$ set by W.H.O and $1.0 \mathrm{ppm}$ as per the USPH standards. The $N i$ content in the waste water samples was found to vary in the range of $0.32 \mathrm{ppm}$ in the month of July to maximum of $3.90 \mathrm{ppm}$ in the month of April.

The overall experimental observed $N i$ concentration was above the maximum limit of $0.1 \mathrm{ppm}$ set by $W . H . O$. The average $\mathrm{Cr}$ content in the industrial effluent samples was found to vary between $0.49 \mathrm{ppm}$ in the month of July which was minimum to maximum of $13.30 \mathrm{ppm}$ in the month of March, which was higher than the maximum permissible limit of $0.05 \mathrm{ppm}$ set by W.H.O [24].

The concentration of $P b$ in the effluent samples was observed to vary in the range of $0.76 \mathrm{ppm}$ in the month of February to $1.75 \mathrm{ppm}$ in the month of October, which was extremely higher than the general standard limit of $0.1 \mathrm{ppm}$ lead set for effluents discharge in inland surface water [25].

The $\mathrm{Fe}$ concentration in the industrial waste water effluent was observed from 1.24 $\mathrm{ppm}$ in the month of June to $15.89 \mathrm{ppm}$ in the month of February. The observed concentration levels of $\mathrm{Fe}$ in the effluent samples collected from the month of August to May 
were above the permissible limit of $3.0 \mathrm{ppm}$ set for effluents discharge in inland surface water [25]. The concentration of $Z n$ in the effluent samples was found to vary in the range of 0.72 to $2.87 \mathrm{ppm}$ throughout the assessment year, while was extremely lower than the general standard limit of $5.0 \mathrm{ppm} \mathrm{Zn}$ set for effluents discharge in inland surface water [25].

In any environmental monitoring study related to pollution of surface water, physicochemical parameters gives valuable information regarding the pollution load. It is found that most of the industries in India are located near the water bodies because of their extensive requirement of water for various industrial activities.

The waste water from such industries are generally discharged in drainages which finally enter the nearby water bodies creating extensive pollution creating threat to the aquatic life and health of surrounding human population.

The most common physico-chemical parameters are $\mathrm{pH}$, conductivity, hardness, alkalinity, suspended and dissolved solids, BOD, COD and DO. These parameters generally decide the extent of pollution and help in planning the waste water treatment technology which is to be adopted. In the present investigation it was observed that the $\mathrm{pH}$ value was minimum of 8.33 in the month of June to maximum of 10.05 in the month of January. It is important here to note that the permissible $\mathrm{pH}$ range of inland surface water subjected to pollution load is 5.5 to 9.0 [25-30].

The conductivity of the industrial waste water effluent was found to vary in the range of $5298 \mu \mathrm{mhos} / \mathrm{cm}$ in the month of October to maximum of $27800 \mu \mathrm{mhos} / \mathrm{cm}$ in the month of June. The majority of physico-chemical parameters like chloride, cyanide, phosphate and total solid content were found to be maximum in the month of March having the respective values of 2340, $0.09,35.2$ and $8755 \mathrm{ppm}$.

The effluent samples collected in the month of May was found to have low DO content of $3.33 \mathrm{ppm}$ and high BOD content of $643 \mathrm{ppm}$. The alkalinity and COD values were reported to be maximum of 1988 and $4410 \mathrm{ppm}$ respectively in the month of February. The hardness and salinity content was reported maximum of 131 and $5.76 \mathrm{ppm}$ during the month of December and June respectively.

\section{CONCLUSION}

With the rapid industrialization in the country, environment pollution by industrial waste has increased tremendously. The discharge of waste water from industries such as oil and surfactants industries, tanneries, pulp and paper, textile, petroleum, chemical industries etc. pollute water bodies.

Nature has an amazing ability to cope up with small amount of waste water and pollution, but it would be hazardous or harmful if billions of gallons of waste water produced everyday are not treated before releasing them back to the environment. The quantities and characteristics of discharged effluent vary from industry to industry depending on the water consumption and average daily product.

Characterization of raw effluent from oil and surfactants industries revealed a wide variation in the effluent quality and quantity over time, characteristic of the different processing stages employed in product manufacturing. Thus, physico-chemical treatment of these effluents is required to bring them into the biodegradable zone and ensure local sewer standards are meeting. 


\section{References}

[1] Di Corcia A., J. Chromatogr. 794 (1998) 165-185.

[2] Verge C., Moreno A., Bravo J., Berna J. L., Chemosphere 44 (2000) 1749-1757.

[3] Renner R., Environ Sci. Technol. 31 (1997) 316A-320A.

[4] Giger W., Brunner P. H., Schaffner C., Science 225 (1984) 623-625.

[5] Ahel M., Giger W., Anal. Chem. 57 (1985) 1577-1583.

[6] Naylor C. G., et al., J. Am. Oil Chem. Soc. 69 (1992) 695-703.

[7] Bennie D. T., et al., Sci. Total Environ. 193 (1997) 263-275.

[8] Blackburn M. A., Kirby S. J., Waldock M. J., Mar Pollut Bull 38 (1999) 109-118.

[9] Ferguson P. L., Iden C. R., Brownwell B. J., Environ. Sci. Technol. 35 (2001) 2428-2435.

[10] Tabata A., et al., Water Sci. Technol. 43(2) (2001) 109-216.

[11] Comber M. H. I., Williams T. D., Stewart K. M., Water Res. 27 (1993) 273-276.

[12] McLeese D. W., et al., Chemosphere 10 (1981) 723-730.

[13] Jobling S. J., Sumpter J. P., Aquat. Toxicol. 1993; 27 (1993) 361-372.

[14] Purdom C. E., Chem. Ecol. 8 (1994) 275-285.

[15] Soto A. M., Justicia H., Wray J. W., Environ. Health Perspect. 92 (1991) 167-173.

[16] Jobling S., et al., Toxicol. Chem. 15 (1996) 194-202.

[17] Action Plan for Industrial Cluster "Dombivali", Maharashtra Pollution Control Board, November 2010. http://www.mpcb.gov.in

[18] Rainwater F. H., Thatcher L. L., U.S. Geol. Surv. Water Supply Papers 1454 (1960) $1-301$.

[19] E. Brown, M. W. Skougstad, M. J. Fishman, 'Methods for collection and analysis of water samples for dissolved minerals and gases', Techniques of Water Resources Investigations of the U.S. Geological Survey, Vol. 160, Book 5, Chapter A1 (1970)

[20] Indian Council of Medical Research (ICMR) Manual of Standards of Quality for Drinking Water Supplies, (1975).

[21] J. D. Hem, 'Study and Interpretation of Chemical Characteristics of Natural Water', $3^{\text {rd }}$ ed., U.S. Geological Survey, Washington (1985).

[22] American Public Health Association (APHA). Standard Methods for Estimation of Water and Wastewater, 19th ed., American Water Works Association, Water Environment Federation, Washington, (1995).

[23] Chen M., Ma L. Q., Soil Science Society of American Journal 65(2) (2010) 491-499.

[24] A. K. De, Environmental Chemistry, pp. 232-272, 4th ed., New Age International (P) Ltd., New Delhi, India (2002).

[25] The Environment (Protection) Rules (1986) Available at: http://www.cpcb.nic.in/GeneralStandards.pdf (assessed on November 2011). 
[26] P. Daniszewski, International Letters of Chemistry, Physics and Astronomy 4 (2012) 112-118.

[27] E. Cyrania, P. Daniszewski, B. Draszawka-Bołzan, International Letters of Chemistry, Physics and Astronomy 5 (2012) 96-103.

[28] E. Cyraniak, P. Daniszewski, B. Draszawka-Bołzan, International Letters of Chemistry, Physics and Astronomy 5 (2012) 88-95.

[29] P. Daniszewski, R. Konieczny, International Letters of Chemistry, Physics and Astronomy 4 (2013) 91-97.

[30] P. Daniszewski, R. Konieczny, International Letters of Chemistry, Physics and Astronomy 4 (2013) 98-104.

[31] P. U. Singare, M. S. Talpade, D. V. Dagli, V. G. Bhawe, International Letters of Chemistry, Physics and Astronomy 8(2) (2013) 94-104

[32] P. U. Singare, M. S. Talpade, D. V. Dagli, V. G. Bhawe, International Letters of Chemistry, Physics and Astronomy 8(2) (2013) 105-112

[33] P. Daniszewski, International Letters of Chemistry, Physics and Astronomy 8(3) (2013) 269-278.

[34] P. Daniszewski, International Letters of Chemistry, Physics and Astronomy 8(3) (2013) 279-287.

[35] P. Daniszewski, International Letters of Chemistry, Physics and Astronomy 10(2) (2013) 218-226. 